\title{
RAISED SERUM TNF-ALPHA, BLOOD SUGAR AND URIC ACID IN PREECLAMPSIA IN THIRD TRIMESTER OF PREGNANCY
}

\author{
Gulati R* \\ * J. N. Medical College, Aligarh Muslim University, Aligarh, U.P. India
}

\section{ABSTRACT}

In preeclapsia, insulin resistance occurs but the exact cause is unknown. It is uncertain whether women destined to develop preeclampsia have preexisting insulin resistance or it is acquired with the development of the disease. Fasting blood samples were collected from 10 normal control pregnant women and from 30 cases of preeclampsia in the third trimester of pregnancy to measure circulating level of glucose, uric acid and tumor necrosis factor-alpha (TNF) concentrations. Preeclampsia was diagnosed as per standard guideline adapted from national high blood pressure education program working group. In control group (n=10) mean age was $25 \pm 3.71$ years, mean sugar level was $86.73 \pm 13.06 \mathrm{mg} / \mathrm{dl}$, uric acid level was $3.25 \pm 0.59 \mathrm{mg} / \mathrm{dl}$ and TNF-alpha level was $9.93 \pm 9.56 \mathrm{pg} / \mathrm{dl}$. In preeclapsia group mean age was $25.56 \pm 3.96$ years, mean sugar level was $93.46 \pm 18.6 \mathrm{mg} / \mathrm{dl}$, uric acid was $6.00 \pm 1.64 \mathrm{mg} / \mathrm{dl}$ and TNF-alpha level was $67.66 \pm 61.83 \mathrm{pg} / \mathrm{dl}$. Statistical analysis done using Kruskal Wallis's test showed significantly raised levels of TNF-alpha ( $\mathbf{p}<0.001)$, uric acid $(p<0.001)$ and blood sugar $(p=0.201)$ in preeclampsia cases. In preeclampsia there was positive significant correlations of raised TNF-alpha with uric acid $(p<0.005)$. Spearman's test for correlation showed positive correlation of TNF-alpha with blood sugar $(p<0.043)$ in cases of preeclampsia. The findings suggest the involvement of cytokines (TNF-alpha) in preeclampsia and may have a role in gestational diabetes mellitus and insulin resistance. In the present study, there was positive association of raised level of TNF-alpha with blood sugar / and uric acid levels.

Key Words: TNF-alpha, glucose, uric acid, gestational diabetes mellitus, preeclampsia.

\section{INTRODUCTION}

TNF-alpha cytokine is a $17 \mathrm{kd}$ peptide, soluble mediator of cellular immunity. One postulated mechanism for development of preeclampsia involves abnormal activation of immune system against fetal allograft. ${ }^{1}$ TNF-alpha may cause tissue damage either directly through activation of protease, collagenase and phospholipase A2 or through oxidant radicals. ${ }^{2}$ Pathologically secreted TNF-alpha directly damages the vascular endothelial cells, reduces regional blood flow, causes occlusion of vessels and increases endothelial permeability. ${ }^{3}$ Endothelial cell injury after TNF-alpha mediated activation of immune system may result in secretion of vasoactive substances and increase in vas- cular permeability and intravascular coagulation. ${ }^{4}$ The development of preeclampsia in patients with gestational diabetes mellitus has been reported. ${ }^{5}$ In preeclamptic women, plasma insulin fasting insulin resistance Index (FIRI), calculated from fasting insulin and glucose concentration have been found significantly higher than the baseline value from 20 and 24 weeks respectively. ${ }^{6}$

The relationship of TNF-alpha in preeclampsia and gestational diabetes mellitus is still unclear. The present study was undertaken to study the role of TNF-alpha in pathophysiology of pregnancy induced hypertension.

Address for correspondence :

Dr. Rajiv Gulati

Dept. of Physiology, BP Koirala Institute of Health Sciences, Dharan, Nepal

Email: rajivamu17@hotmail.com

Received Date : $12^{\text {th }}$ December, 2004

Accepted Date : $11^{\text {th }}$ May, 2005 


\section{MATERIAL AND METHOD}

\section{Selection of cases}

Clinically diagnosed cases of preeclampsia $(n=30)$ aged between 20 to 40 years, in third trimester of pregnancy were selected from in and out patient departments of Obstetric and Gynaecology, Jawaharlal Nehru medical college, Aligarh Muslim University. The cases were selected as per guideline adapted from national high blood pressure education program working group report on high blood pressure in pregnancy. ${ }^{7}$ Normal pregnant women in third trimester of pregnancy $(\mathrm{n}=10)$ were taken as control. Informed consent was obtained from all the participants and collecting of samples was not in a random fashion but with full purposiveness.

\section{Exclusion criteria}

Women with cardiac, hepatic and renal diseases were not included in the study. Similarly patients with past history of hypertension, metabolic disorders like diabetes mellitus, lipid disorders were excluded from the study.

\section{Blood Sample collection}

$10 \mathrm{ml}$ of venous blood was collected and serum was separated and stored at $-20^{\circ} \mathrm{C}$ until required for measurement of TNF-alpha. Serum uric acid and blood sugar were analyzed in a freshlycollected serum. Uric acid was analyzed by phophotungstate method. Serum TNF- alpha was analyzed by the ELISA technique using a kit (Diclone kit, France). Fasting blood sugar was assayed as per the standard glucose oxidase method.

\section{Estimation of TNF- alpha}

The TNF-alpha kit is a solid phase sandwich enzyme linked immunosorbant assay. A monoclonal antibody specific for TNF- alpha has been coated on the well of microtitre strips and samples, including standards of known. The TNF-alpha concentration of control and unknown were pipette into the wells. During the first incubation, the TNF-alpha antigen and a biotinylated monoclonal antibody specific for TNF- alpha were simultaneously incubated. After washing, the enzyme streptoverdin peroxidase was added. After incubation and washing, to remove all the unbound enzyme, a substrate solution which acts on bound enzyme was added to induce a colored reaction product. The intensity of this colored product was directly proportional to the concentration of TNF-alpha present.

\section{Statistical analysis}

The data were analysed by non-parametric Krushal Wallis test. Correlations among blood sugar, uric acid and TNF alpha were calculated using Spearman's test for cases $(n=30)$ and controls $(n=10)$

\section{RESULT}

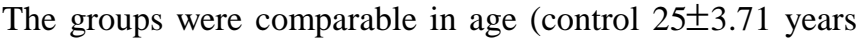
versus cases $25.56 \pm 3.96$ years). The mean levels of blood sugar, uric acid and TNF-alpha levels were $86.73 \pm 13.06 \mathrm{mg} / \mathrm{dl}$, $3.25 \pm 0.59 \mathrm{mg} / \mathrm{dl}$ and $9.3 \pm 9.5 \mathrm{pg} / \mathrm{dl}$ respectively in controls $(n=10)$. Whereas, in cases $(n=30)$ blood sugar, uric acid and TNF-alpha were $93.46 \pm 18.6 \mathrm{mg} / \mathrm{dl}, 6.00 \pm 1.64 \mathrm{mg} / \mathrm{dl}$ and $67.66 \pm 61.83 \mathrm{pg} / \mathrm{dl}$ respectively. The TNF-alpha levels were significantly higher in preeclampsia than in control $(\mathrm{p}<0.001)$. Similarly, uric acid was also higher in preeclampsia group as compared to control group ( $\mathrm{p}<0.001)$. The TNF-alpha showed significant positive correlation with uric acid $(\mathrm{p}<0.01)$ in controls and with blood sugar in cases $(\mathrm{p}<0.05)$.

Table I : Comparison of levels of blood sugar, uric acid and TNF-alpha between cases and control

\begin{tabular}{llll}
\hline \multicolumn{1}{c}{ Variables } & \multicolumn{1}{c}{ Control $(\mathbf{n}=\mathbf{1 0})$} & \multicolumn{1}{c}{ Cases $(\mathbf{n}=30)$} \\
\hline Age (years) & $25 \pm 3.71$ & $25.56 \pm 3.91$ & \\
TNF alpha in blood $(\mathrm{pg} / \mathrm{dl})$ & $9.3 \pm 9.56$ & $67.66 \pm 61.83^{*}$ & $(\mathrm{p}<0.001)$ \\
Blood sugar $(\mathrm{mg} / \mathrm{dl})$ & $86.73 \pm 13.06$ & $93.46 \pm 18.6 \quad(\mathrm{p}<0.0201)$ \\
Serum uric acid $(\mathrm{mg} / \mathrm{dl})$ & $3.25 \pm 0.59$ & $6.00 \pm 1.64 *$ & $(\mathrm{p}<0.0001)$ \\
\hline
\end{tabular}

Table II : Spearman's correlation among blood sugar, uric acid and TNF alpha Among cases and controls

\begin{tabular}{lcccc}
\hline Variables & Correlation Coefficient & Sugar & TNF-alpha & Uric acid \\
\hline Sugar & & 1.000 & 0.229 & 0.033 \\
& Sig. (2-tailed) & 0 & 0.155 & 0.839 \\
TNF-alpha & $\mathrm{N}$ & 49 & 40 & 40 \\
& & 0.229 & 1.000 & 0.432 \\
Uric acid & Sig. (2-tailed) & 0.155 & 0 & 0.005 \\
& $\mathrm{~N}$ & 40 & 40 & 40 \\
& & 0.033 & 0.432 & 1.000 \\
& Sig. (2-tailed) & 0.839 & 0.005 & 0 \\
& $\mathrm{~N}$ & 40 & 40 & 40 \\
\hline
\end{tabular}

Test used: Kruskal Wallis Test 


\section{DISCUSSION}

The results in the present study showed significant raised levels of TNF-alpha ( $p<0.001)$, uric acid $(\mathrm{p}<0.0001)$ and blood sugar $(\mathrm{p}<0.201)$ in preeclamptic women after 28 week of gestation ( $3^{\text {rd }}$ trimester). Similar studies were done by many researchers in the past and in recent time. The present study has correlated blood sugar, uric acid and TNF-alpha level in third trimester of pregnancy. This study not explaining variables such as TNFalpha levels in different gestational period are the limitations of this research work. Further study could be taken using more variables. The role of TNF-alpha in gestational diabetes is unclear as some reported against its role in blood sugar ${ }^{7}$ where as other supported TNF -alpha as cytokine playing role in raising blood sugar specially in preeclampsia patients. ${ }^{8}$ Many studies have shown positive relation of the role of TNF-alpha in preeclampsia ${ }^{8}$ and the present study also showed positive correlation with TNF-alpha in preeclampsia. Raised TNF alpha also correlated positively with blood sugar and uric acid levels in preeclamptic patients.

The above hypothesis may be due to the role of TNF- alpha in insulin resistance with raised level of fasting insulin index, calculated from ratio of plasma insulin level and fasting glucose level (FIRI). ${ }^{6}$ Insulin resistance precedes clinical onset of disease has been reported recently by Anim et al 2004. Recent literature also reported that raised blood sugar seen in gestational diabetes mellitus (GDM) has been positively correlated with raised blood pressure which is a hallmark of preeclampsia. The present study may have explained the role of cytokine TNF-alpha in patho physiology of the pregnancy induced hypertension. ${ }^{5}$

Spearman's correlation test showed raised TNF-alpha having significant correlation with increased blood glucose $(\mathrm{p}<0.043)$ in preeclamptic cases. Raised uric acid level was also significantly and positively associated with TNF alpha levels if both case and control were considered together. The indication may be that TNF alpha as well as uric acid levels in blood are strongly associated and may have a role in the pathophysiology of the disease. Hyperuricemia of more than $6 \mathrm{mg} / \mathrm{dl}$ correlates with severity of the disease. ${ }^{9}$ A study on 215 hypertensive pregnant women in their $3^{\text {rd }}$ trimester showed hyperuricemia and renal involvement in preeclampsia. ${ }^{10}$ Ranjan et al showed uric acid level as one of the parameter used in early diagnosis of pregnancy induced hypertension. ${ }^{12}$ Raised levels of uric acid were found to be associated with twin pregnancy. ${ }^{13}$

\section{CONCLUSION}

In conclusion this study showed positive association between TNF-alpha, uric acid and blood sugar levels in preeclamptic pregnancies. This is a significant finding in the light of complications of pregnancy induced hypertension.

\section{ACKNOWLEDGMENT}

I am thankful to Dr.B.H.Paudel, Associate Professor of Physiology, BPKIHS, Dharan, Nepal for statistical assitance.

\section{REFERENCES}

1. Sibai BM. Immunological aspects of preeclampsia. Clin.Obstet. Gynaecol. 1991; 34: 27-34.

2. Le J, Valeek J. Biology of disease. TNF and IL-1: Cytokines with multiple overlapping biological activities. Lab. Invest. 1987; 56: 234-248.

3. Hunt JS. Cytokines network in uteroplacental unit, macrophages as pivotal regulatory cell. J. Reprod. Immunol .1989, 16:1-25.

4. Ari K, Lee F; Miyajima A, Miyatake S, Ari N, Yokata T .Cytokine coordinators of immune and inflammatory responses. Ann. Rev. Biochem. 1990, 56:248.

5. Yogev Y, Langero, Brustman I, Rosen B. Preeclampsia and gestational diabetes mellitus (GDM).Does correlation exist early in Pregnancy .J .Matern .Fetal. Neonatal .Med, 2004, 15(1):39-43.

6. Anim-Nyame N, Sooranne Sr, JonesJ, Alangh band, Zadeh S, Steer PJ, John MR. Insulin resistance and preeclampsia: A role of tumor necrosis factor-alpha. Gynaecol. Endocrinol. 2004, 18(3):117-23.

7. F Garry Cunnigram, Norman F Grant, Kenneth J Leveno, Larry C, Gilstrap, John C. Hauth, Katharine D Wenstrom. Hyertensive disorders in pregnancy. William textbook of Obstretics and Gynaecology, international edition, Mcgrow Hill. $21^{\text {st }}$ edition. p-569.

8. Nunez-Gonzala, Sanabria-Vera CJ, Romero-Adrian T. Measurement of serum concentrations of tumor necrosis factor- alpha and its soluble receptors in normal and preeclamptic pregnant patients. Invest. Clin 2001; 42(3): 171-81.

9. Garron C, Broso P. Uric acid and preeclampsia. Minerve Ginecol.1997; 49:213-16.

10. Yoshida A, Morozumi K, Shinmur J,Nagami Y.Preeclampsia and tubular dysfunction. Nippon. Sdnka. Fujirika. Gakkai. Zasshi. 1987; 39:9-16.

11. Voto LS, Ilia R, Darbon Grosso HA, Imaz FU, Margulis M. Uric acid levels: a useful index of severity of preeclampsia and perinatal prognosis.J.Perinatal.med.1988; 16:123-6.

12. Ranjan Mustaphi, Sarala Gopalan, Lakhbir Dhaliwed, AK Sarkar Hyperuricemia and pregnancy induced hypertension. Ind. J. Med. Sci. 1996; 50: 68-71.

13. Koike T, Ogawa S, Kuwata T, Sato I. Evaluation of serum uric acid level preceding the clinical manifestation of preeclampsia in twin pregnancies. Gynae. Obst. Invest. 1997, 44: 97-101. 